\title{
Aksjologiczny i inwestycyjny wymiar odpowiedzialności za człowieka w polityce aktywizacji i ekonomii społecznej
}

\section{Wprowadzenie}

Radykalne zmiany społeczne i gospodarcze nasilające się w ostatnich latach budzą powszechny niepokój zarówno jednostek, jak i całych społeczeństw. Rosnące poczucie zagrożenia sprawia, że coraz mocniej rozwija się międzynarodowa debata nad kierunkami rozwoju społecznego w skali Europy i świata. Wielość podmiotów w niej uczestniczących prowadzi do powstania różnorodnych idei, teorii i koncepcji. Trwa poszukiwanie nowych kierunków i modeli rozwoju, które nie tylko ograniczają się do wyjaśniania nowych kwestii społecznych, lecz przede wszystkim bazują na wskazywaniu możliwych kierunków przeobrażeń.

Nowe modele ładu społecznego w wymiarze światowym, europejskim czy krajowym szczególny nacisk kładą na działalność gospodarczą człowieka, nie tylko w wąskim rozumieniu, jako przedsiębiorczej aktywności jednostek, ale także w szerokim - jako stwarzania warunków dla zaspokajania potrzeb społeczności i jej rozwoju.

W polityce społecznej kwestia pracy jawi się jako fundamentalny problem, lecz zarazem bariera rozwoju w skali całego świata. Specyfika pracy wynika $\mathrm{z}$ faktu, że radykalnie przekształca ona charakter życia codziennego i zmienia najbardziej osobiste doświadczenia człowieka. Jednocześnie w wymiarze makroekonomicznym uwidacznia się charakterystyczna dla współczesnej polityki społecznej, zacieśniająca się wzajemnie zależność pomiędzy czynnikami globalnymi - z jednej strony, a indywidualnymi dyspozycjami jednostek.

W polskiej polityce społecznej, zarówno w jej wymiarze teoretycznym, jak i praktycznym, mocno zaznaczają się europejskie inspiracje 
dotyczące m.in. problematyki rynku pracy. Europeizacja polskiej polityki społecznej, pomimo różnorodnych interpretacji tego wpływu, wskazuje na ewolucyjną zmianę, który ma doprowadzić do powstania podobieństw między narodowymi systemami polityki społecznej. Jej rezultatem będzie silny rozwój ponadnarodowego modelu polityki społecznej. Pod wpływem intensywnego rozwoju międzynarodowych regulacji socjalnych systemy w krajach członkowskich będą się do siebie upodabniać. Podobieństwom tym będzie służyć zarówno przyjęcie prymatu regulacji międzynarodowych nad krajowymi, jak i współpraca międzynarodowa, wzajemne zależności i postępująca koordynacja działań ${ }^{\text {. }}$

Chociaż wspólna europejska polityka społeczna w swoich założeniach prowadzić ma do podniesienia poziomu życia obywateli, to jednak poszczególne rozwiązania budzą w wielu krajach sprzeciw społeczny. Jego źródłem są odmienności w systemach wartości, na których te projekty są oparte.

Celem niniejszego opracowania jest ukazanie aksjologicznego wymiaru nauki społecznej Jana Pawła II, a szczególnie encykliki Centesimus annus. Chodzi o jej znaczenie dla polskiej polityki aktywizacji i rozwoju sektora ekonomii społecznej.

Pomimo implementacji europejskich wzorców do polityki rynku pracy nadal stajemy wobec nierozwiązanych problemów aktywizacji zawodowej i społecznej dużych grup społecznych. Rozszerzanie pola inspiracji dla refleksji naukowej i poszukiwanie czynników, które pozwalałyby - pomimo ograniczeń - funkcjonować jednostkom w pluralistycznym społeczeństwie organizowanym przez rynek - jest nadal istotne, zarówno w wymiarze heurystycznym, jak i praktycznym.

W pluralistycznym społeczeństwie społeczna nauka Kościoła i rekomendacje z niej płynące stanowią natchnienie dla wielu ludzi, którzy działając indywidualnie lub łącząc się na różne sposoby w grupy, stowarzyszenia i organizacje, tworzyli „wielki ruch obrony osoby ludzkiej i ochrony jej godności, przez co przyczynili się pośród zmiennych wydarzeń dziejowych do budowania społeczeństwa bardziej sprawiedliwego, a przynajmniej przeciwstawiali się niesprawiedliwości i próbowali ją ograniczyć" ${ }^{\prime 2}$.

K. Głąbicka, Europejski model socjalny, Radom 2012, s. 9-10.

CA 3. 
Dlatego też wyraźnie podkreślona zostaje społeczna rola Kościoła w budowaniu fundamentów ładu społecznego. „Kościół [...] wypowiada się na temat określonych sytuacji ludzkich, indywidualnych i wspólnotowych, narodowych i międzynarodowych, i formułuje w ten sposób swoje nauczanie, prawdziwy corpus doktrynalny, który pozwala mu analizować zjawiska społeczne, wypowiadać się na ich temat i wskazywać kierunki właściwego rozwiązywania problemów, które z nich wynikają”.

\section{Gospodarka rynkowa w encyklice Centesimus annus}

Wśród 14 encyklik Jana Pawła II kategoria pracy i organizacji życia społecznego i gospodarczego (kluczowa dla konstrukcji zasad porządku społecznego) w warunkach współczesnego świata pojawiła się dwukrotnie. Encykliki Laborem exercens z 14 września 1981 roku oraz o 10 lat późniejsza Centesimus annus z 1 maja 1991 roku są odpowiedzią na przemiany globalizacyjne i wyzwania gospodarcze w wymiarze ogólnoświatowym. Pierwsza z encyklik analizuje rolę pracy jako czynnika rozwojowego zarówno w wymiarze społecznym (pomnażanie dobrobytu kraju), jak też indywidualnym. Osobowy charakter pracy wyraża się w podkreślonym już wcześniej przez Leona XIII fakcie, iż siła pracy tkwi w osobie i jest właściwością osoby, która jej używa i na której pożytek natura ją przeznaczyła. Także najczęściej przytaczane za Janem Pawłem II stwierdzenie, że „Praca jest dobrem człowieka - dobrem jego człowieczeństwa - przez pracę bowiem człowiek nie tylko przekształca przyrodę, dostosowując ją do swoich potrzeb, ale także urzeczywistnia siebie jako człowiek, a także poniekąd bardziej staje się człowiekiem", stawia ten rodzaj aktywności człowieka jako jedno z centralnych wyzwań współczesności.

Druga z encyklik, Centesimus annus, jest zarówno dialogiem z nauczaniem Leona XIII, jak i potwierdzeniem oraz rozwinięciem jego diagnozy systemów gospodarczo-społecznych, a także odpowiedzią Kościoła na najbardziej aktualne w chwili ogłoszenia tej encykliki wydarzenia polityczne.

Jan Paweł II docenia osiągnięcia gospodarcze kapitalizmu i jego wiodącą (po upadku systemów socjalistycznych) rolę w globalnej gospodarce. Papież pozytywnie waloryzuje „konstruktywny wysiłek odbudowy

3 CA 5 . 
społeczeństwa demokratycznego, rządzącego się sprawiedliwością społeczną, która pozbawia komunizm rewolucyjnego potencjału"4. Próby te polegają zwykle na staraniach o utrzymanie mechanizmów wolnego rynku.

Nie absolutyzując roli niewidzialnej ręki rynku, stwierdza, że „zarówno wewnątrz poszczególnych narodów, jak i w relacjach międzynarodowych wolny rynek jest jak najbardziej skutecznym narzędziem wykorzystywania zasobów i zaspokajania potrzeb"s. Równocześnie podkreśla, iż istnieją potrzeby zbiorowe i jakościowe, których nie da zaspokoić za pośrednictwem rynku i jego mechanizmów. „Istnieją dobra, których ze względu na ich naturę nie można i nie należy sprzedawać i kupować" 6 .

Jan Paweł II przestrzega przed zagrożeniem dla wartości etycznych, wynikającym $\mathrm{z}$ niewłaściwej implementacji zasad liberalizmu. W jego oczach nie straciło na znaczeniu zagrożenie związane $\mathrm{z}$ taką strukturą społeczną, która zapewnia „absolutną dominację kapitału oraz własności narzędzi produkcji nad podmiotowością i wolnością pracy człowieka"”.

Jerzy Michałowski, analizując zawarty w encyklice katalog zagrożeń wolnego rynku, wymienia za papieżem, oprócz nierównowagi struktury ekonomicznej, także:

- życie ekonomiczne całkowicie zdominowane przez pragnienie zysku, oparte na niezrównoważonym układzie kapitał-praca, które nawet przy poprawnym rachunku ekonomicznym może prowadzić do poniżania ludzi i obrażania ich godności,

- traktowanie pracy wyłącznie jako czynnika produkcji, którego koszty należy minimalizować,

- wymuszanie umów o pracę, które nie biorą pod uwagę najbardziej elementarnych zasad sprawiedliwości społecznej,

- usuwanie przez rynek na margines pewnych osób ze względu na nieustający postęp techniczno-organizacyjny; z tego powodu z rynku rugowane są osoby najsłabsze, m.in. ludzie starzy, część młodzieży czy też kobiety, 
- konsumpcjonizm, który jest wynikiem rosnącego dobrobytu w wielu krajach, powiązany z brakiem kryteriów do poprawnego odróżnienia nowych i doskonalszych form zaspokajania ludzkich potrzeb od potrzeb sztucznie wytwarzanych, przeszkadzających kształtowaniu się dojrzałej osobowości; jego skutkiem jest wytwarzanie nawyków i stylów życia obiektywnie niegodziwych i szkodliwych dla fizycznego i duchowego rozwoju człowieka,

- kryzys ekologiczny wypływający z postaw i konsumpcyjnych stylów życia, którego przejawem i efektem jest nieuporządkowane dążenie do zaspokajania wszelkiego rodzaju potrzeb, powodujące nadmierne zużycie zasobów Ziemi i prowokujące bunt natury raczej przez człowieka tyranizowanej niż rządzonej.

Wśród najważniejszych i aktualnych kwestii społecznych współczesnego świata w kontekście reformy gospodarki rynkowej jawi się problem bezrobocia. Jego wysoka stopa we wszystkich prawie krajach europejskich, Afryce i Azji jest wyzwaniem dla światowej efektywnej polityki społecznej. W zakresie rynku pracy niezbędne i pilne jest podjecie skoordynowanych działań prowadzących do możliwie najwyższego stopnia zatrudnienia i włączania poprzez aktywność społeczną wszystkich jednostek w główny nurt życia społeczeństwa. Rozwiązania te wymagają solidnych aksjologicznych podstaw, bowiem „bez zakorzenienia w prawdzie człowiek i społeczeństwo wystawione są na przemoc namiętności i jawne bądź ukryte uwarunkowania".

\section{Aksjologiczne podstawy gospodarowania}

Pozytywna ocena przemian społecznych zachodzących w systemie kapitalistycznym w Europie wymaga uwzględnienia - poza analizami społeczno-ekonomicznymi - trzeciego wymiaru - etycznego. Można więc stwierdzić, iż encyklika Centesimus annus wprowadziła na nowe tory dyskurs pomiędzy katolicką nauką Kościoła a naukami ekonomicznymi. Obszary tego wzajemnego wpływu są bardzo szerokie. Najistotniejsza jednak jest przedstawiona w tym dokumencie wizja ładu gospodarczego,

8 J. Michałowski, Centesimus annus - jaki kapitalizm?, w: Jan Paweł II, „Centesimus annus”. Tekst i komentarze, red. F. Kampka, C. Ritter, Lublin 1998, s. 232-233.

9 CA 36. 
którego fundamentami są: rynek, zysk, praca, przedsiębiorczość i własność prywatna.

Chociaż papież Jan Paweł II niechętnie używa pojęcia „kapitalizm”, to jednak, opisując jego przemiany, podkreśla ich społeczny wymiar. „W niektórych krajach i w pewnych dziedzinach podjęto konstruktywny wysiłek odbudowy po zniszczeniach wojennych społeczeństwa demokratycznego, rządzącego się sprawiedliwością społeczną, która pozbawia komunizm rewolucyjnego potencjału w postaci wyzyskiwanych i uciskanych rzesz ludzkich. Próby te polegają zwykle na staraniach o utrzymanie mechanizmów wolnego rynku, zapewnienie przez stabilność pieniądza i pewność stosunków społecznych - warunków stałego i zdrowego rozwoju gospodarczego, który ludziom pozwala własną pracą budować lepszą przyszłość dla siebie i dla swych dzieci. Równocześnie kraje te starają się o to, by mechanizmy rynkowe nie stały się jedynym punktem odniesienia dla życia społeczeństwa i dążą do poddania ich kontroli społecznej"10. Wytworzone w toku jego ewolucji takie elementy, jak: liczne możliwości pracy, istnienie solidnego systemu ubezpieczeń społecznych, wolność zrzeszania się w związki zawodowe, zabezpieczenie w przypadku bezrobocia, sprawiają, że człowiek ma możliwość wykonywania pracy w jej „godności”. Z drugiej zaś strony przemiany gospodarki liberalnej w rynkową gospodarkę społeczną ułatwiły jej akceptację na gruncie podstawowych zasad życia społecznego.

Uznanie mechanizmów rynkowych (z pewnymi ograniczeniami) jako najbardziej skutecznego mechanizmu wykorzystania zasobów i zaspokajania potrzeb prowadzi do akceptacji immanentnej właściwości ryn$\mathrm{ku}$ - konkurencji jako zasady regulującej stosunki społeczne. Papież nie wypowiada się wprost o współzawodnictwie i jego granicach.

Podkreśla konieczność minimalnego poziomu solidarności, który pozwala najsłabszym na rzeczywisty udział w rynku i życiu społecznym. „W imię sprawiedliwości i prawdy nie wolno dopuścić do tego, aby podstawowe ludzkie potrzeby pozostały nie zaspokojone i do wyniszczenia $\mathrm{z}$ tego powodu ludzkich istnień. Konieczne jest też udzielenie ludziom potrzebującym pomocy w zdobywaniu wiedzy, we włączaniu się w system wzajemnych powiązań, w rozwinięciu odpowiednich nawyków, które pozwolą im lepiej wykorzystać własne zdolności i zasoby. Ważniejsze

${ }^{10}$ CA 19. 
niż logika wymiany równowartości i niż różne formy sprawiedliwości, które się z tym wiążą, jest to, co należy się człowiekowi, ponieważ jest człowiekiem, ze względu na jego wzniosłą godność. To, co należy się człowiekowi, musi gwarantować możliwość przeżycia i wniesienia czynnego wkładu w dobro wspólne ludzkości”"1. Tak więc niezależnie od obszaru czy charakteru analiz pierwotną aksjologiczną podstawą regulacji stosunków społecznych i gospodarczych jest godność osoby ludzkiej.

Encyklika wyraźnie podkreśla dualistyczny charakter rozwoju gospodarczego, wskazując jego aprobowany z punktu widzenia nauczania Kościoła kierunek. To taki system, który „uznaje zasadniczą i pozytywną rolę przedsiębiorstwa, rynku, własności prywatnej i wynikającej z niej odpowiedzialności za środki produkcji, oraz wolnej ludzkiej inicjatywy w dziedzinie gospodarczej”. Z drugiej zaś strony to „system, w którym wolność gospodarcza nie jest ujęta w ramy systemu prawnego, wprzęgającego ją w służbę integralnej wolności ludzkiej i traktującego jako szczególny wymiar tejże wolności, która ma przede wszystkim charakter etyczny i religijny" ${ }^{12}$. Zatem gospodarka prawnie nieuporządkowana, pozbawiona zakotwiczenia w wartościach, w świetle społecznej nauki Kościoła musi być zdecydowanie odrzucona.

Jan Paweł II dokonuje także etycznej oceny drugiego - poza konkurencją - mechanizmu regulacyjnego gospodarki rynkowej, czyli zysku. „Kościół uznaje pozytywną rolę zysku jako wskaźnika dobrego funkcjonowania przedsiębiorstwa: gdy przedsiębiorstwo wytwarza zysk, oznacza to, że czynniki produkcyjne zostały właściwie zastosowane, a odpowiadające im potrzeby ludzkie - zaspokojone"13. Temu stwierdzeniu towarzyszy równie mocne ostrzeżenie przed sytuacjami, w których zysk jest jedynym wskaźnikiem dobrego funkcjonowania przedsiębiorstwa, a pomimo poprawnego rachunku ekonomicznego ludzie, którzy stanowią jego najcenniejszy majątek, są poniżani i obraża się ich godność.

Jednak najbardziej podniosłą tezą tej encykliki jest wskazanie wspólnotowego charakteru przedsiębiorstw. Uznanie nie tylko ekonomicznych, lecz również społecznych funkcji zysku sprawia, iż zaakcentowana jest ludzka twarz procesów gospodarczych. „Celem zaś przedsiębiorstwa nie

\footnotetext{
11 CA 34.

${ }^{12} \mathrm{CA} 42$.

13 CA 35.
} 
jest po prostu wytwarzanie zysku, ale samo jego istnienie jako wspólnoty ludzi, którzy na różny sposób zdążają do zaspokojenia swych podstawowych potrzeb i stanowią szczególną grupę służącą całemu społeczeństwu. Zysk nie jest jedynym regulatorem życia przedsiębiorstwa; obok niego należy brać pod uwagę czynniki ludzkie i moralne, które z perspektywy dłuższego czasu okazują się przynajmniej równie istotne dla życia przedsiębiorstwa"14.

Wspólnotowy duch przenika także omówione w dokumencie funkcje przedsiębiorczości. Papież zgodnie z antropologiczno-społecznym paradygmatem katolickiej nauki społecznej w centrum ekonomii przedsiębiorstwa umieszcza człowieka. „Głównym bogactwem człowieka jest wraz z ziemią sam człowiek. To właśnie jego inteligencja pozwala odkryć możliwości produkcyjne ziemi i różnorakie sposoby zaspokojenia ludzkich potrzeb. To jego zdyscyplinowana praca i solidarne współdziałanie z innymi umożliwia tworzenie coraz szerszych i coraz bardziej godnych zaufania wspólnot pracy, mających dokonywać przekształceń środowiska naturalnego i środowiska społecznego"'15.

Zaspokajanie zróżnicowanych potrzeb ludzkich wymaga współdziałania wielu osób. I tu pojawia się zadanie dla przedsiębiorców. „Zorganizowanie takiego wysiłku, rozplanowanie go w czasie, zatroszczenie się, by rzeczywiście odpowiadał temu, czemu ma służyć, oraz podjęcie koniecznego ryzyka jest dziś także źródłem bogactwa społeczeństwa. W ten sposób staje się coraz bardziej oczywista i determinująca rola zdyscyplinowanej i kreatywnej pracy ludzkiej oraz - jako część istotna tej pracy - rola zdolności do inicjatywy i przedsiębiorczości” ${ }^{31}$. Realizacja tych zadań doskonali samego przedsiębiorcę, wymaga od niego pracy nad takimi ważnymi cnotami, jak rzetelność, pracowitość, roztropność w podejmowaniu uzasadnionego ryzyka, wiarygodność i wierność w relacjach międzyosobowych, męstwo we wprowadzaniu w życie decyzji trudnych i bolesnych, lecz koniecznych dla wspólnej pracy przedsiębiorstwa i dla zapobieżenia ewentualnym katastrofom.

I wreszcie ostatni z fundamentów kapitalistycznej gospodarki - własność prywatna. Katolicka nauka społeczna utwierdzała - od encykliki

\footnotetext{
14 Tamże.

15 CA 32.

16 SRS 15.
} 
Rerum novarum - prawo człowieka do posiadania własności prywatnej i konieczność istnienia takiego ładu instytucjonalnego, który ją zabezpiecza. Encyklika nie odnosi się do takich współczesnych problemów, jak rozkład bogactwa, rosnące dysproporcje społeczne czy nierówności w zakresie możliwości jego tworzenia bądź pomnażania. Papież ogranicza się do określenia warunków legitymizacji własności prywatnej w płaszczyźnie moralnej i prawnej. „Własność środków produkcji tak w przemyśle, jak i w rolnictwie, jest słuszna wtedy, gdy służy użytecznej pracy; przestaje natomiast być uprawniona, gdy nie jest produktywna, lub kiedy służy przeszkadzaniu pracy innych, lub uzyskiwaniu dochodu, którego źródłem jest nie globalny rozwój pracy i społecznego majątku, lecz wyzysk, niegodziwe wykorzystywanie, spekulacja i rozbicie solidarności świata pracy. Własność taka nie ma żadnego usprawiedliwienia i w obliczu Boga i ludzi jest nadużyciem" ${ }^{\prime 17}$.

\section{Przesłania encykliki w polskiej polityce społecznej}

Szczególna rola polityki społecznej wynika z faktu, że łączy ona w sobie teorię i praktykę, dotyczy każdej jednostki i całych zbiorowości. Polska literatura przedmiotu - już od końca ubiegłego wieku - wielowątkowo odnosiła się do nowych paradygmatów polityki społecznej, inspirując do prowadzenia lokalnych i krajowych badań oraz zachęcając praktyków do innowacyjnych rozwiązań instytucjonalnych. Główny jednak nacisk położony został na poszukiwanie polskiego modelu polityki społecznej, będącego odpowiedzią nie tylko na tendencje globalne i europejskie, lecz także na transformację systemu społeczno-gospodarczego i jej dysfunkcje.

Kluczowymi problemami w tych dociekaniach były takie kwestie, jak: diagnozowanie rzeczywistości społecznej, budowanie i analiza modeli polityki społecznej jako działalności praktycznej, niwelowanie niepożądanych skutków gospodarki rynkowej, określanie roli państwa i innych podmiotów w polityce społecznej i ich relacji do rynku oraz jego reguł, budowa stosunków społecznych i struktury społecznej zgodnie z uznanymi za ważne dla społeczeństwa wartościami, poszukiwanie i promowanie najbardziej efektywnych sposobów wprowadzania zmian w społeczeństwie.

${ }^{17}$ CA 43. 
Julian Auleytner, ukazując istotę polityki społecznej, określa ją „jako działalność państwa, samorządów i organizacji pozarządowych, której celem jest poprawa położenia materialnego, asekuracja przed ryzykami życiowymi i wyrównanie szans życiowych grup społecznych, ekonomicznie i socjalnie najsłabszych" ${ }^{\text {"18 }}$.

Także Adam Kurzynowski, wskazując na rolę podmiotów publicznych w sferze społecznej, akcentuje aksjologiczny wymiar działań w zakresie rozwoju społecznego. Ich zadanie sprowadza do kształtowania ogólnych warunków pracy i bytu ludności, prorozwojowych struktur społecznych oraz stosunków społecznych opartych na równości i sprawiedliwości społecznej, sprzyjających zaspokajaniu potrzeb społecznych na dostępnym poziomie ${ }^{19}$.

Przypisywanie państwu roli głównego podmiotu polityki społecznej jest stwierdzeniem powszechnym i akceptowanym przez teoretyków i praktyków. W ogólnych rozważaniach akcentuje się jego zadania socjalne realizowane bądź bezpośrednio, bądź też za pośrednictwem samorządów lokalnych czy też organizacji społecznych.

Również Ryszard Szarfenberg podkreśla konieczność instrumentalnego wykorzystania władzy w państwie do osiągnięcia dobrobytu wszystkich obywateli ${ }^{20}$. Autor dostrzega konieczność wprowadzenia pozarynkowych mechanizmów, bowiem nawet polityka nastawiona na trwały sukces gospodarczy - rozumiany jako zapewnienie ciągłego wzrostu produktu, zrównującego się z potrzebami obywateli - nie wystarczy dla zapewnienia wszystkim obywatelom wszechstronnego dobrobytu na odpowiednim poziomie. Dlatego, że część potrzeb ma pozagospodarczy charakter, a także dlatego, że podział produktu według pracy nie daje gwarancji dobrobytu dla wszystkich ${ }^{21}$.

Odmienności katolickiej nauki społecznej od modelowych rozwiązań polityki społecznej uwidaczniają się w głównych akcentach tych paradygmatów. Nauka Kościoła, uznając prawo człowieka do dobrobytu, nie czyni jednak z tego ostatniego celu rozwojowego społeczeństw i nie

${ }_{18}$ J. Auleytner, Polityka społeczna - ciągłość i zmiany, Warszawa 2004, s. 102-104; tenże, Polityka społeczna w Polsce i na świecie, Warszawa 2011, s. 362-263.

${ }_{19}$ Polityka społeczna, red. A. Kurzynowski, Warszawa 2006, s. 9.

${ }^{20}$ R. Szarfenberg, Krytyka i afirmacja polityki społecznej, Warszawa 2008, s. 34.

${ }^{21}$ Tamże, s. 27. 
stawia państwa w roli strażnika. W przytaczanej encyklice mocno podkreślona jest jego funkcja, jaką jest „czuwanie nad realizowaniem praw ludzkich w dziedzinie gospodarczej i kierowanie nim; tu jednak główna odpowiedzialność spoczywa nie na Państwie, ale na poszczególnych ludziach oraz na różnych grupach i zrzeszeniach, z których się składa społeczeństwo. [...] obowiązkiem Państwa jest popieranie działalności przedsiębiorstw poprzez tworzenie warunków zapewniających możliwości pracy, dostarczanie bodźców tam, gdzie owa działalność jest niewystarczająca, albo przez udzielanie pomocy w chwilach kryzysu"22.

Papież, analizując rolę państwa w gospodarce i społeczeństwie, wskazuje na obowiązek budowy ładu prawnego, instytucjonalnego i politycznego, którego fundamentem jest poczucie bezpieczeństwa w zakresie gwarancji indywidualnej wolności i własności, a ponadto stabilność pieniądza oraz istnienie sprawnych służb publicznych. W sferze polityki społecznej dopuszczalne są funkcje zastępcze. Są one usprawiedliwione pilnymi potrzebami wiążącymi się z dobrem wspólnym, powinny być, w miarę możności, ograniczone w czasie, by nie poszerzać zakresu interwencji państwa ze szkodą dla wolności, tak gospodarczej, jak i obywatelskiej. Papież krytykuje stały i szeroki zakres interwencji. Interweniując bezpośrednio i pozbawiając społeczeństwo odpowiedzialności, państwo opiekuńcze powoduje utratę ludzkich energii i przesadny wzrost publicznych struktur, w których - przy ogromnych kosztach - raczej dominuje logika biurokratyczna aniżeli troska o to, by służyć korzystającym z nich ludziom. Przy tym często pewnego rodzaju potrzeby wymagają odpowiedzi wykraczającej poza porządek tylko materialny, takiej mianowicie, która potrafi wyjść naprzeciw głębszym potrzebom ludzkim ${ }^{23}$.

Widać więc wyraźnie płaszczyzny zgodności i rozbieżności modeli polityki społecznej i paradygmatu katolickiej nauki społecznej. Zasadnicza różnica (jak sadzę, nie do pogodzenia w przyszłości) dotyczy roli państwa i jego zadań. Zdecydowana większość modelowych rozwiązań $\mathrm{w}$ polityce społecznej stawia państwo $\mathrm{w}$ roli dominującego podmiotu w tym obszarze. Choć jego zadania są w tych wizjach zróżnicowane (od usługodawcy do koordynatora), to jednak na nim spoczywa główna odpowiedzialność za kształt polityki socjalnej. Natomiast w kwestiach

${ }^{22}$ CA 48.

${ }^{23}$ Tamże. 
pomocy potrzebującym, grupom słabszym i defaworyzowanym przez rynek, zwłaszcza w sytuacjach kryzysowych, a także w zakresie organizacji warunków życia społecznego i gospodarczego, wpływających na kształt struktury społecznej, istnieje pełna zgoda.

Interwencyjny charakter pomocy współgrający z misją państwa kształtującego taki ład społeczny, który determinująco wpływa na kształt struktury społecznej, rozwinął Julian Auleytner ${ }^{24}$. W jego koncepcji zawarte są główne wątki przesłania papieskiego. Punktem wyjścia jest oparcie jej na klasycznej definicji Konstantego Krzeczkowskiego i uznanie, że polityka społeczna ma na celu badanie zmian zachodzących w strukturze społecznej pod wpływem nie tylko działalności państwa, ale i innych podmiotów, takich jak sektor komercyjny oraz organizacje pozarządowe.

Autor, uznając prawdziwość tych celów, wysuwa tezę, iż istnieje konieczność zarówno zróżnicowania odpowiedzialności jednostek za kształtowanie warunków własnego życia, jak i zgodnie z zasadą pomocniczości - różnicowania roli podmiotów i form wsparcia przez nie udzielanych. Zróżnicowane potrzeby poszczególnych segmentów struktury społecznej, wśród których wyróżnił on: elity, biurokrację, stan średni, pracę zależną i peryferie zmarginalizowane czasowo bądź trwale, są uzasadnieniem istnienia i rozwoju wielosektorowej polityki społecznej.

Zasadniczo opiekuńczość płynąca ze strony sektora publicznego nie jest potrzebna dwóm pierwszym grupom, gdyż one ją kreują. Obie te grupy, korzystając z dostępu do władzy i korzyści z niej wynikających, zapewniają sobie wystarczającą pozycję socjalną. Stan średni to grupa ekonomicznie niezależna od państwa dzięki posiadanej własności prywatnej. Zwalniają oni państwo od poszukiwania dla nich miejsc pracy, a ponadto płacą państwu podatki. To klasyczny przykład realizacji samozatrudnienia, a tym samym „samoopiekuńczości”. W stosunku do stanu średniego nie mamy jednak - zdaniem autora - dotychczas wyodrębnionej polityki wspierania pracy niezależnej, choć miejsce jest tu na wszystkie trzy sektory. Państwo realizuje swoją opiekuńczość przede wszystkim wobec ludzi pracy zależnej (pracowników) i grup (z)marginalizowanych. Efektem opiekuńczości państwa jest ruchliwość ludzi pomiędzy grupami.

\footnotetext{
${ }^{24}$ J. Auleytner, Czy Polska jest państwem opiekuńczym?, w: Aktywna polityka społeczna $z$ perspektywy Europy socjalnej, red. K. Piątek, A. Karwacki, Toruń 2007, s. 28.
} 
W zaproponowanym modelu należy zwrócić uwagę na potencjalne możliwości i instrumenty wsparcia różnych warstw społecznych. Aktywność kierowana do/i poprzez stan średni może przybierać różne formy. Są nimi: przedsiębiorczość społeczna, społeczna odpowiedzialność firm, społecznie odpowiedzialne inwestowanie, społeczne inwestowanie na rzecz społeczności, strategiczna efektywna filantropia i rozwój. Formy te mogłyby tworzyć czwarty sektor polityki obywatelskiej, który osiągałby nowy typ wartości, tzw. wartość mieszaną. Wartość mieszana składa się z trzech komponentów: społecznego, ekonomicznego oraz ochrony środowiska naturalnego, stanowiąc integralną i niepodzielną całość ${ }^{25}$. Przedstawiony model rozwija zawarte w nauce Jana Pawła II wątki, wskazuje także współczesne instrumenty oddziaływania pobudzające odpowiedzialność za dobro wspólne i rozwijające ducha wspólnoty.

Wydaje się, iż także inne rozwijające się współcześnie koncepcje polityki społecznej współgrają z wizją zarysowaną w encyklice Centesimus annus. Przyjmują one prymat działań antycypacyjnych nad działaniami o charakterze interwencyjnym ${ }^{26}$ i zmierzają w kierunku budowy pożądanego wzorca ładu społecznego oraz wyznaczenia celowego zakresu kształtowania struktury społecznej. Już Stanisław Ossowski podkreślał, iż wizja ładu społecznego opartego na systemie porozumień zbiorowych (tak mocno akcentowana przez Jana Pawła II) jest dla polityki społecznej fundamentalna, bowiem „wszystkie koncepcje, w myśl których wielostopniowe porozumienie i więź społeczna miały zastąpić przymus, zapewnić szerokim rzeszom obywateli udział w społecznym planowaniu i pogodzić swobodne ścieranie się idei i skali wartości z racjonalnie skoordynowaną gospodarką" ${ }^{27}$, gwarantują możliwość przeprowadzenia zmiany społecznej.

Obok modelu antycypacyjnej polityki społecznej coraz szerzej toruje sobie miejsce paradygmat inwestycyjnej polityki społecznej stawiającej sobie za cel rozwój kapitału ludzkiego i społecznego, tak aby dzięki stymulowaniu samorozwoju jednostek ograniczać w przyszłości potrzebę

\footnotetext{
${ }^{25}$ Tenże, Polityka społeczna - ciagłość i zmiany, s. 102-104; tenże, Polityka społeczna w Polsce i na świecie, s. 362-263.

${ }^{26}$ T. Szumlicz, Ubezpieczenie w polityce społecznej. Teksty i komentarze, Warszawa 2015, S. $31-33$.

${ }^{27}$ S. Ossowski, O osobliwościach nauk społecznych, Warszawa 1962, s. 104.
} 
korzystania z pomocy i wyposażyć je w kompetencje, które pozwolą im samodzielnie zadbać o swój dobrobyt.

Mirosław Grewiński definiuje inwestycyjną politykę społeczną jako „działanie nastawione przede wszystkim na tworzenie kapitału ludzkiego (i społecznego) wśród pokolenia młodych. Inwestycja w przyszłość dokonuje się [...] poprzez aktywną politykę na rzecz rodziny i aktywną politykę rynku pracy oraz poprzez edukację i permanentne szkolenia" ${ }^{28}$.W ramach takiego podejścia należy jego zdaniem traktować politykę społeczną jako inwestycję w dobrobyt społeczny, a nakłady powinny iść w kierunku edukacji ustawicznej i zawodowej oraz usług aktywizacyjnych i integracyjnych.

Inwestycyjna polityka społeczna akcentująca rozwój jednostek i ich doskonalenie oddaje w pełni przesłanie papieskie, kłóci się jednakże $\mathrm{z}$ uznaniem roli państwa $\mathrm{w}$ tym procesie. O ile twórcy tego paradygmatu zakładają dominującą rolę państwa i sektora publicznego w procesie jej implementacji, o tyle nauka Kościoła widzi wyłącznie jego pomocniczy charakter. On zaś najpełniej ujawnia się w innym obywatelskim modelu polityki społecznej. Dominuje w nim dążenie do rozwiązań gwarantujących nie tylko sprawność i efektywność, lecz także wyznaczających podmiotowość obywateli i ich zaangażowanie w życie publiczne, co skłania do budowy reguł kooperacji społeczeństwa i państwa także w sferze rozwiązań socjalnych.

Jednostki budujące wspólnotę lokalną są głównymi adresatami polityki społecznej w mikroskali. Są też jej aktywnymi kreatorami. Efektywne rozwiązywanie problemów społecznych w środowisku lokalnym, zapewnienie członkom zbiorowości realizacji praw socjalnych, zahamowanie procesów rozwarstwienia społecznego i dążenie do spójności społecznej wymagają pobudzenia i wykorzystania wszelkich, także pozapaństwowych i pozaekonomicznych zasobów.

Katarzyna Głąbicka upatruje w solidarności szczególnego typu więzi społecznych, które nie tylko są wyznacznikiem przynależności do wspólnoty i podkreślają jej jedność w staraniach o lepszy kształt życia ludzkiego, ale także uznają ją za zasadę życia społecznego „wspomagającą działania

\footnotetext{
${ }^{28}$ M. Grewiński, Inwestycyjna polityka społeczna jako koncepcja odroczonego bezpieczeństwa socjalnego, w: Polityka społeczna dla bezpiecznego rozwoju, red. M. Leszczyński, M. Kubiak, Gdańsk 2015, s. 47.
} 
na rzecz wyrównywania nierówności społecznych między regionami, grupami społecznymi i pokoleniami. Solidarność jest zarazem wartością, jak i postawą, która przyczynia się do zbliżania standardu i poziomu życia różnych grup ludności”29.

Mirosław Grewiński i Stanisław Kamiński w pojęciu obywatelskiej polityki społecznej zawarli „aktywną działalność organizacji pozarządowych, podmiotów gospodarki społecznej oraz innych inicjatyw oddolnych, służącą zaspokajaniu potrzeb obywateli oraz łagodzeniu i/lub eliminowaniu kwestii społecznych, przy wykorzystaniu potencjału kapitału społecznego w duchu współodpowiedzialności za spójność społeczną i bezpieczeństwo socjalne"30.

Autorzy zwracają także uwagę, że warunkiem jej realizacji jest występująca wśród członków wspólnoty świadomość nie tylko swoich praw, ale i obowiązków. To także przenikające encyklikę Centesimus annus odwołanie do dobra wspólnego oraz wrażliwości na potrzeby innych członków wspólnoty.

\section{Aktywizacja i ekonomia społeczna - nowy wymiar odpowiedzialności}

Dynamicznie zmieniające się warunki gospodarcze i społeczne sprawiają, iż w kwestii polityki społecznej wyłaniają się nowe kierunki rozwoju tej dziedziny w Polsce, wyznaczające ramy funkcjonowania instytucji publicznych i organizacji pozarządowych, determinujące także działania wszystkich uczestników tego systemu.

Takim nowym kierunkiem jest model aktywnej polityki społecznej (APS), z jego instrumentami określanymi mianem ,aktywnych lub aktywizujących" ${ }^{31}$. Chociaż u źródeł tej koncepcji leży wola ograniczania pasywnych transferów społecznych, to jednak wprowadzenie instrumentów warunkowego wsparcia skłania jednostki do aktywności w zakresie zapewniania warunków materialnych dla siebie i swojej rodziny,

\footnotetext{
${ }^{29}$ K. Głąbicka, Prekursorzy socjalnego wymiaru Europy, Radom 2010, s. 59.

${ }^{30}$ M. Grewiński, S. Kamiński, Obywatelska polityka społeczna, Warszawa 2007, s. 12.

${ }^{31}$ A. Karwacki, Papierowe skrzydła. Rzecz o spójnej polityce aktywizacji, Toruń 2010, s. 71-91.
} 
podnoszenia własnej zdolności zatrudnieniowej czy też przejawiania przedsiębiorczości społecznej rozwijanej w sektorze ekonomii społecznej.

Mimo tego, że koncepcja ta zakłada wykorzystanie zasobów instytucji niepublicznych (organizacji pozarządowych) do prowadzenia programów aktywizujących i różnych wspieranych aktywności na rynku pracy, to jednak dominuje w niej idea państwa - jako głównego podmiotu skłaniającego do pracy, systemu pozytywnych i negatywnych bodźców adresowanych do niższych warstw społeczeństwa, które mają zniechęcić do życia ze świadczeń socjalnych i zachęcać do aktywności zawodowej i odzyskania samodzielności ekonomicznej ${ }^{32}$.

Przy wszystkich zastrzeżeniach dotyczących zarówno sposobów implementacji tej polityki, jak i pola wolności podmiotów, którym udzielane jest wsparcie, trzeba uznać, że sprzyja ona niwelowaniu problemów rozwojowych związanych z pracą i zatrudnieniem. Polega więc nie tylko na zwalczaniu wykluczenia społecznego i ubóstwa poprzez politykę prozatrudnieniową, ale także na tworzeniu spójności, pobudzaniu solidarności i aktywnych postaw uczestnictwa obywatelskiego ${ }^{33}$.

Zdaniem Arkadiusza Karwackiego trzy równorzędne filary tej koncepcji - zatrudnienie, integracja i obywatelstwo - stanowią o jej istocie. I chociaż w praktyce nacisk położony jest na zatrudnienie, to jednak pozostałe dwa są nie mniej ważne dla wizji ładu społecznego i świadczą o wzrastających kompetencjach społecznych, aktywności obywatelskiej czy też zdolności do lepszego wypełniania ról rodzinnych ${ }^{34}$.

Jan Paweł II także akcentuje wagę i obowiązek zaangażowania jednostek w życie społeczne na poziomie ponadrodzinnym. Wspólne działania budują nowe więzi, tworzą trwałe grupy, inicjują aktywność organizacji pozarządowych, ruchów społecznych czy wolontariatu, zmieniającą jakość relacji międzyludzkich. „Dojrzewają one jako prawdziwe wspólnoty osób i umacniają tkankę społeczną, zapobiegając jej degradacji, jaką jest anonimowość i bezosobowe umasowienie, niestety częste we współczesnym społeczeństwie. Osoba ludzka żyje i «podmiotowość społeczeństwa»

${ }^{32}$ R. Szarfenberg, Definicje, zakres i konteksty polityki społecznej, w: Polityka społeczna. Podręcznik akademicki, red. G. Firlit-Fesnak, M. Szylko-Skoczny, Warszawa 2009, s. 404.

${ }^{33}$ K. Głąbicka, Współczesne wyzwania dla polskiej polityki społecznej do 2020 r., w: Polityka społeczna wobec wyzwań i zmian zachodzacych we wspótczesnym świecie, red. M. Kubiak, Gdańsk 2014, s. 63-65.

${ }^{34}$ Polityka aktywizacji w Polsce, red. A. Karwacki, H. Kaszyński, Toruń 2008, s. 34. 
wzrasta wtedy, kiedy wiele różnych relacji wzajemnie się ze sobą splata. Często jednostka dusi się dziś pomiędzy dwoma biegunami: Państwem i rynkiem. Niekiedy wydaje się, jakoby istniała ona jedynie jako wytwórca i nabywca towarów, czy też jako przedmiot administracji państwowej i zapomina się, że ani rynek, ani Państwo nie są celem międzyludzkiego współżycia, bowiem ono samo w sobie posiada szczególną wartość, której Państwo i rynek mają służyć”35.

Pojawienie się w polityce społecznej organizacji pozarządowych przyczyniło się do odrodzenia idei ekonomii społecznej ${ }^{36}$. Chociaż dzisiaj dość powszechne jest uznanie roli ekonomii społecznej w systemie gospodarczym i społecznym, to jednak ciągle kontrowersje dotyczą jej istoty i zadań. Najczęściej podkreśla się fakt, że sprowadza się ona do prymatu działania na rzecz członków społeczności nad maksymalizacją zysku. Cechami odróżniającymi instytucje gospodarki społecznej od przedsiębiorstw opartych na bazie kapitałowej są: prymat celów indywidualnych i społecznych ponad kapitałem i zyskiem, dobrowolne i otwarte członkostwo, demokratyczna kontrola przez członków (wyjątkiem są fundacje), połączenie interesów członków z interesem ogólnym, rozwijanie i przyjmowanie wartości solidarności i odpowiedzialności, autonomiczne zarządzanie i niezależność od władz państwowych, przeznaczanie nadwyżki finansowej na stały rozwój celów i usług dla członków lub interesu społecznego ${ }^{37}$.

Ekonomia społeczna pełni wiele prorozwojowych funkcji, wśród których Jerzy Hausner wymienia: tworzenie materialnej bazy dla działania organizacji obywatelskich, promowanie alternatywnych form kredytowania, wzmacnianie kapitału społecznego, służenie regeneracji lokalnej przestrzeni publicznej, sprzyjanie urzeczywistnianiu idei obywatelskości, ułatwianie reformowania sektora usług publicznych ${ }^{38}$.

Ewa Leś pozytywnie ocenia warunki prawne i społeczne rozwoju tego sektora w Polsce ${ }^{39}$, co sprawia, że gospodarka społeczna zyskuje coraz

35 CA 49.

${ }^{36}$ M. Gagacka, Nierówności społeczne jako wyzwanie dla ekonomii społecznej, w: Wspótczesne wyzwania dla lokalnej polityki społecznej, red. M. Gagacka, K. Głąbicka, Radom 2009, s. 443-468.

${ }_{37}$ W. Kwaśnicki, Gospodarka społeczna z perspektywy ekonomii liberalnej, „Trzeci Sektor” (2005), nr 2, s. 13-14.

${ }^{38}$ J. Hausner, Zarządzanie publiczne, Warszawa 2008, s. 219.

39 E. Leś, Nowa ekonomia społeczna - wybrane koncepcje, „Trzeci Sektor” (2005), nr 2, s. 44. 
większą popularność. Problemy dotyczą sposobów jej implementacji. W wymiarze aksjologicznym ważna jest reguła udzielania wsparcia potrzebującym w sposób nienaruszający ich godności. Także w wymiarze praktycznym działalność motywująca do własnej aktywności, pobudzająca „moc podmiotową" jednostek, a równocześnie integrująca nie tylko jednostki, lecz służby socjalne jest powszechnie akceptowana, nie kłóci się z założeniami głównych sił politycznych - neoliberalnych, konserwatywnych i socjaldemokratycznych. Walorem gospodarki społecznej jest jej zdolność do systemowej inkluzji środowisk marginalizowanych. Można więc stwierdzić, iż przywraca ona odpowiedzialność jednostek za własny los, nie pozbawiając ich pomocy w uzyskiwaniu samodzielności.

Z punktu widzenia budowania społeczeństwa obywatelskiego ważne jest wykorzystanie zasobów społecznych i ekonomicznych trzeciego sektora w gospodarce społecznej, takich jak: zaangażowanie, orientacja na zadania, wykorzystanie pracy wolontariuszy czy też innowacyjność w poszukiwaniu najbardziej optymalnych rozwiązań problemów społecznych.

Wśród słabości tego segmentu gospodarki - z perspektywy ekonomicznej - wskazuje się na niską efektywność zatrudnienia w obszarze ekonomii społecznej, określanej jako quasi-rynkowa, tworzenie miejsc pracy, które z racji subsydiowania sprzeczne są z racjonalnością rynkową i naruszają zasadę uczciwej konkurencji. Warto jednak podkreślić, że pobudzenie przedsiębiorczości społecznej i jej wspieranie dokonuje się w obszarach nieatrakcyjnych dla komercyjnego rynku, oraz to, iż celem tych działań jest zwiększanie zdolności zatrudnieniowej prowadzące jednostki do otwartego rynku pracy.

Inną słabością jest zjawisko stygmatyzacji oraz zagrożenia dla wolności jednostek. Warunkowość wsparcia jest mocno sprzężona z koniecznością podporządkowania się odgórnie zarzuconym regułom i wyrzeczenia się części wolności. Ponadto przyjęte w ramach tych reguł rozwiązania trwale etykietują jednostki, powodując, iż w odczuciu własnym oraz otoczenia społecznego traktowane są jako inne, a często gorsze ${ }^{40}$.

Odnosząc wizje rozwoju sektora gospodarki społecznej w Polsce do założeń encykliki Centesimus annus, należy wyraźnie zaakcentować różnice

\footnotetext{
${ }^{40}$ M. Gagacka, Beneficjenci aktywnej polityki rynku pracy, w: Polityka aktywizacji w Polsce. Usługi reintegracji w sektorze gospodarki społecznej, red. M. Grewiński, M. Rymsza, Warszawa 2011, s. 282-284.
} 
w tych podejściach. Po pierwsze, papieski postulat tworzenia fundamentów gospodarki społecznej dotyczy całego systemu gospodarczego i powolnej ewolucji systemów liberalnych w tym kierunku. Wydaje się jednak, że rozwiązania przyjęte w ramach ekonomii społecznej i wartości, na których jest oparta, są nie do zaakceptowania we współczesnej gospodarce. Ekonomia społeczna według zaprezentowanego modelu jest bowiem tylko uzupełnieniem komercyjnego rynku.

Po drugie, dla indywidualistycznie zorientowanych społeczeństw aktywna polityka społeczna i ekonomia społeczna są łatwe do zaakceptowania głównie z tego powodu, że sprowadzają się do promocji polityki zatrudnienia (nawet jeśli na odmiennych warunkach), a przez to ograniczania transferów społecznych ${ }^{41}$.

Wreszcie, pokazując różnice podejść nauki Kościoła i paradygmatu aktywizacji, trzeba stwierdzić, że akcentowany w encyklice ludzki i wspólnotowy wymiar aktywności nie ogranicza się wyłącznie do wąskiego segmentu gospodarki. Łatwość, z jaką elity polityczne i duża część społeczeństwa zaakceptowały ten model ekonomii społecznej, nie zamyka go na nowe rozwiązania. Nie zwalnia także od poszukiwań efektywnych społecznie, a nie wyłącznie ekonomicznie sposobów osiągania jak największej spójności społecznej w ramach całego systemu społecznego i gospodarczego. Dyskurs poparty rzetelną oceną skuteczności celów i form przyjętych rozwiązań z całą pewnością rozwojowi tej koncepcji będzie służył. Nie może ona jednak zastąpić całościowego spojrzenia na problemy społeczne i stanowić jedynego instrumentarium ich rozwiązywania.

\section{Zakończenie}

Komplikacja i dynamika narastania współczesnych kwestii społecznych oraz ich umiędzynarodowienie sprawiają, że poszukiwanie skutecznych sposobów ich rozwiązywania jest procesem trudnym i wieloaspektowym. Czerpanie inspiracji tylko z teorii i praktycznych doświadczeń nawet najbardziej rozwiniętych krajów nie przekłada się na rozwiązania w innych częściach Europy i świata. Zróżnicowany potencjał gospodarczy, niska sprawność instytucji, odrębności kulturowe, różnice w systemach

${ }^{41}$ M. Rymsza, Aktywizacja w polityce społecznej. W strone rekonstrukcji europejskich Welfare States?, Warszawa 2013, s. 143. 
wartości są głównymi barierami upowszechniania modeli socjalnych w skali Europy. Wprowadzenie rynkowych mechanizmów do polityki społecznej, koncentracja wyłącznie na efektywności, jak dotąd nie przyniosła spodziewanych efektów, a wręcz przeciwnie - stała się źródłem pojawiania się nowych problemów.

Zrozumiałe jest zainteresowanie polityków społecznych problematyką rynku i pracy, jej brak stanowi jedną z głównych przyczyn narastania konfliktów społecznych i pojawiania się nowych kwestii społecznych. Nowe modele ładu społecznego $\mathrm{w}$ wymiarze światowym, europejskim czy krajowym szczególny nacisk kładą na działalność gospodarczą człowieka, nie tylko na przedsiębiorczą aktywność jednostek, ale także w szerokim znaczeniu - na stwarzanie warunków dla zaspokajania potrzeb społeczności i jej rozwoju. Pomimo wprowadzania europejskich wzorców do polityki rynku pracy nadal istnieje wiele nierozwiązanych problemów aktywizacji zawodowej i społecznej. Rozszerzanie pola inspiracji dla refleksji naukowej jest istotne, zarówno w wymiarze heurystycznym, jak i praktycznym.

W tym dyskursie ważną rolę powinna odegrać społeczna nauka Kościoła, nie tylko jako inspiracja naukowa, ale przede wszystkim jako motywacja do działania dla tych wszystkich, którzy kierując się zawartymi w jej przesłaniu wartościami, odnajdywali motywację do budowania społeczeństwa bardziej sprawiedliwego, przeciwstawiania się niesprawiedliwości i jej ograniczania.

Zainteresowanie człowiekiem w społecznym nauczaniu Kościoła w ostatnich dekadach wzbogacone zostało analizą uwarunkowań gospodarczych, które w znacznym stopniu determinują miejsce i role jednostki w społeczeństwie. Encyklika Centesimus annus pokazuje indywidualny i wspólnotowy wymiar odpowiedzialności, jest wezwaniem do aktywności ekonomicznej i społecznej jednostek, a zarazem nakazem odpowiedzialności innych podmiotów za tworzenie warunków dla podmiotowości, sprawstwa zmarginalizowanych jednostek. Popularyzacja przesłania i nauki Jana Pawła II może dyskusję nad rolą i zadaniami polityki społecznej i gospodarczej znacznie wzbogacić i ożywić. 


\section{Bibliografia}

Auleytner J., Czy Polska jest państwem opiekuńczym?, w: Aktywna polityka społeczna z perspektywy Europy socjalnej, red. K. Piątek, A. Karwacki, Wydawnictwo Edukacyjne Akapit, Toruń 2007, s. 25-42.

Auleytner J., Polityka społeczna - ciagłość i zmiany, Wydawnictwo Wyższej Szkoły Pedagogicznej Tw P, Warszawa 2004.

Auleytner J., Polityka społeczna w Polsce i na świecie, Wydawnictwo Wyższej Szkoły Pedagogicznej TwP, Warszawa 2011.

Gagacka M., Beneficjenci aktywnej polityki rynku pracy, w: Polityka aktywizacji $w$ Polsce. Ustugi reintegracji w sektorze gospodarki społecznej, red. M. Grewiński, M. Rymsza, Wydawnictwo Wyższej Szkoły Pedagogicznej TwP, Warszawa 2011, s. 261-268.

Gagacka M., Nierówności społeczne jako wyzwanie dla ekonomii społecznej, w: Współczesne wyzwania dla lokalnej polityki społecznej, red. M. Gagacka, K. Głąbicka, PT Ps - Politechnika Radomska, Radom 2009, s. 443-446.

Głąbicka K., Europejski model socjalny, Wydawnictwo Politechniki Radomskiej, Radom 2012.

Głąbicka K., Prekursorzy socjalnego wymiaru Europy, Wydawnictwo Politechniki Radomskiej, Radom 2010.

Głąbicka K., Współczesne wyzwania dla polskiej polityki społecznej do 2020 r., w: Polityka społeczna wobec wyzwań i zmian zachodzacych we współczesnym świecie, red. M. Kubiak, Wydawnictwo UG, Gdańsk 2014, s. 57-72.

Grewiński M., Inwestycyjna polityka społeczna jako koncepcja odroczonego bezpieczeństwa socjalnego, w: Polityka społeczna dla bezpiecznego rozwoju, red. M. Leszczyński, M. Kubiak, Instytut Politologii Uniwersytetu Gdańskiego, Gdańsk 2015, s. 40-55.

Grewiński M., Kamiński S., Obywatelska polityka społeczna, PTPs - Wyższa Szkoła Pedagogiczna Tw P, Warszawa 2007.

Hausner J., Zarządzanie publiczne, Wydawnictwo Naukowe Scholar, Warszawa 2008.

Jan Paweł II, Encyklika Centesimus annus, przedruk: Libreria Editrice Vaticana, Włocławek 1991.

Jan Paweł II, Encyklika Sollicitudo rei socialis, Ośrodek Chrześcijańskiej Myśli Społecznej Augustinum, Warszawa 1988.

Karwacki A., Papierowe skrzydła. Rzecz o spójnej polityce aktywizacji, Wydawnictwo UMK, Toruń 2010. 
Kwaśnicki W., Gospodarka społeczna z perspektywy ekonomii liberalnej, „Trzeci Sektor" (2005), nr 2, s. 10-35.

Leś E., Nowa ekonomia społeczna - wybrane koncepcje, „Trzeci Sektor” (2005), nr 2, s. 36-45.

Michałowski J., Centesimus annus - jaki kapitalizm?, w: Jan Paweł II, „Centesimus annus”. Tekst i komentarze, red. F. Kampka, C. Ritter, Redakcja Wydawnictw KUL, Lublin 1998, s. 227-246.

Ossowski S., O osobliwościach nauk społecznych, PwN, Warszawa 1962.

Polityka aktywizacji w Polsce, red. A. Karwacki, H. Kaszyński, Wydawnictwo Naukowe Uniwersytetu Mikołaja Kopernika, Toruń 2008.

Polityka społeczna, red. A. Kurzynowski, Szkoła Główna Handlowa w Warszawie - Oficyna Wydawnicza, Warszawa 2006.

Rymsza M., Aktywizacja w polityce społecznej. W stronę rekonstrukcji europejskich Welfare States?, Wydawnictwo IFiS PAN, Warszawa 2013.

Szarfenberg R., Definicje, zakres i konteksty polityki społecznej, w: Polityka społeczna. Podręcznik akademicki, red. G. Firlit-Fesnak, M. Szylko-Skoczny, Wydawnictwo Naukowe Pwn, Warszawa 2009, s. 21-36.

Szarfenberg R., Krytyka i afirmacja polityki społecznej, Wydawnictwo IFiS PAn, Warszawa 2008.

Szumlicz T., Ubezpieczenie w polityce społecznej. Teksty i komentarze, Warszawa 2015.

\begin{abstract}
Abstrakt
W niniejszym opracowaniu przedstawiono analizę wybranych płaszczyzn oddziaływania nauczania Jana Pawła II na polską politykę społeczną. Poszukiwanie efektywnych sposobów rozwiązywania problemów społecznych jest rosnącą i naglącą potrzebą współczesności. Fenomen marginalizacji społecznej i wykluczenia dużych grup w społeczeństwie utrzymuje się pomimo przemian społecznych i wzrostu gospodarczego. Pokazuje on, że ani polityka społeczna, ani gospodarcza nie są w stanie korzeni tych zjawisk wyeliminować. Uwzględnienie w europejskim i krajowym dyskursie społecznej nauki Kościoła nie tylko rozszerza płaszczyzny diagnozy, ale także wprowadza niezbędny w budowie ładu społecznego fundament aksjologiczny. Encyklika Centesimus annus jest od ponad dekady tego heurystycznym i praktycznym przykładem.
\end{abstract}


Axiological and investment dimension of the responsibility for the man in politics of the activation and social economy

\begin{abstract}
This study presents an analysis of the impact of selected areas of the teaching of John Paul II on Polish social policy. The search for effective ways of solving social problems is growing and urgent need for the present. The phenomenon of social marginalization and exclusion of large sections of our society persists despite social change and economic growth. It shows that neither the economic nor social policy are not able to eliminate the roots of these phenomena. Taking into account the European and national discourse Church's social doctrine not only expands the level of the diagnosis, but also introduces an essential axiomatic foundation in the construction of the social order. The Encyclical Centesimus annus is more than a decade this heuristic and practical example.
\end{abstract}

